\title{
Effect of high temperatures on the mechanical behaviour of hybrid cement
}

\author{
B. Qu ${ }^{\mathrm{a}, \mathrm{b} \bowtie}$, A. Fernández Jiménez ${ }^{\mathrm{b}}$, A. Palomo ${ }^{\mathrm{b}}$, A. Martin ${ }^{\mathrm{a}}$, J.Y. Pastor ${ }^{\mathrm{a}}$ \\ a. Departmento de Ciencia de los Materiales -CIME. Universidad Politécnica de Madrid. E28040-Madrid \\ b. Eduardo Torroja Institute for Construction Science (CSIC). E28033-Madrid, Spain \\ $\triangle$ qubooil@gmail.com
}

\begin{abstract}
The high-temperature mechanical behaviour of a pre-industrial hybrid alkaline cement (HYC) was studied. The HYC in question contained $30 \%$ Portland clinker and $70 \%$ of a blend of slag, fly ash and a solid activator (mix of alkaline salts with a predominance of $\mathrm{Na}_{2} \mathrm{SO}_{4}$ ). The material was tested during exposure to high temperatures to establish its compressive and bending strength and elastic modulus, as well as fracture toughness, analysed using an innovative methodology to notch the hydrated cement paste specimens. Post-thermal treatment tests were also run to assess residual mechanical strength after $2 \mathrm{~h}$ of exposure to temperatures ranging from $400{ }^{\circ} \mathrm{C}$ to $1000{ }^{\circ} \mathrm{C}$. TG/DTA, MIP and SEM were deployed to ascertain heat-induced physical-chemical changes in the structure. The higher mechanical strength during and after treatment exhibited by the hardened hybrid alkaline cement than the CEM I 42.5R ordinary portland cement (OPC) paste used as a reference was associated with the lower water and portlandite content found in HYC. Pseudo-plastic behaviour was observed at high temperatures in the loaded HYC in the tests conducted during exposure.
\end{abstract}

KEYWORDS: Hybrid cement; High temperature; Mechanical behaviour; Fracture toughness; Porosity.

Citation/Citar como: Qu, B.; Fernández-Jiménez, A.; Palomo, A.; Martín, A.; Pastor, J.Y. (2020) Effect of high temperatures on the mechanical behaviour of hybrid cement. Mater. Construcc. 70 [337], e213 https://doi.org/10.3989/ mc.2020.13318

RESUMEN: Efecto de las elevadas temperaturas en el comportamiento mecánico de un cemento híbrido. El objetivo de este trabajo es determinar el comportamiento mecánico a elevadas temperaturas de un cemento alcalino híbrido pre-industrial (HYC) formado por un 30\% de clinker de cemento Portland y un $70 \%$ de una mezcla de escoria, cenizas volantes y un activador sólido (coctel de sales alcalinas con predominio del $\mathrm{Na}_{2} \mathrm{SO}_{4}$ ). Se realizaron dos tipos de ensayos mecánicos: i) ensayos in situ a diferentes temperaturas para determinar la resistencia mecánica (compresión y flexión), y el módulo de elasticidad. Para determinar la tenacidad a la fractura se utilizó una novedosa metodología experimental para introducir entallas en las probetas de pasta de cemento hidratado. ii) experimentos post tratamiento térmico para evaluar la resistencia mecánica residual después de dos horas de exposición a una temperatura que oscila entre 400 y $1000^{\circ} \mathrm{C}$. Las técnicas TG / DTA, MIP, y SEM se utilizaron para determinar los cambios físico-químicos en la estructura del material debido a dicha exposición. Los resultados obtenidos indican que las pastas de cemento alcalino híbrido endurecido presentan una resistencia mecánica a altas temperaturas (in situ y post térmico) superior a las del Cemento Portland Ordinario empleado como referencia (CEM I 42.5R). Este comportamiento se asocia a que las pastas endurecidas del HYC tienen un menor contenido de agua y portlandita. Indicar que se ha observado que a altas temperaturas y bajo carga (in situ) las pastas de HYC presentan un comportamiento seudo-plástico.

PALABRAS CLAVE: Cemento híbrido; Alta temperatura; Comportamiento mecánicas; Tenacidad a fractura; Porosidad.

ORCID ID: B. Qu (https://orcid.org/0000-0001-5893-0989); A. Fernández-Jiménez (https://orcid.org/0000-0002-57212923); A. Palomo (https://orcid.org/0000-0002-6964-2269); A. Martin Sanz (https://orcid.org/0000-0003-1291-948X); J.Y. Pastor (https://orcid.org/0000-0003-3561-5999).

Copyright: (C) 2020 CSIC. This is an open-access article distributed under the terms of the Creative Commons Attribution 4.0 International (CC BY 4.0) License. 


\section{INTRODUCTION}

Characterised by a very high value for money, ordinary Portland cement (OPC)-based concrete is, second only to water, the material most assiduously used in the world $(1,2)$. Unlike wood, plastic and other construction inputs, portland cement-based materials are non-flammable and exhibit low thermal conductivity, which would apparently translate into good fire resistance. High temperatures can induce significant deterioration in OPC-based concrete, mortar and paste microstructure and properties, however (1). The calcium silicate hydrate (C-S-H gel) phase to which OPC primarily owes its mechanical properties loses significant amounts of water at temperatures of $50{ }^{\circ} \mathrm{C}$ to $200{ }^{\circ} \mathrm{C}$ and decomposes altogether over $800{ }^{\circ} \mathrm{C}$. At the same time, water is released from AFt- and AFm-type phases at temperatures of $100{ }^{\circ} \mathrm{C}$ to $400{ }^{\circ} \mathrm{C}$, whilst portlandite decomposes at around $450 / 460{ }^{\circ} \mathrm{C}$ and calcium carbonate at $>600{ }^{\circ} \mathrm{C}$ (3-6). All those changes and reactions induced by high temperatures have a very significant adverse impact on a material's physical-chemical and mechanical performance (7). The outcome is severe cement paste deterioration that compromises the integrity and safety of the concrete in which it is used.

In another vein, Portland cement manufacture is known to produce greenhouse gas emissions, accounting for $5 \%$ to $8 \%$ of all $\mathrm{CO}_{2}$ emissions worldwide, primarily as a result of high cement output (8). In light of growing urbanisation and infrastructure needs, especially in developing countries, portland cement manufacture will foreseeably continue to rise (9), and with it $\mathrm{CO}_{2}$ emissions. If allowed to continue unfettered, growth will hinder compliance with the United Nations' 2030 Sustainable Development Goals. The scientific community and the cement industry are therefore working to develop both alternative binders that would reduce the Portland clinker factor in today's cements and new $0 \%$ Portland clinker cements.

Belite, sulfo-belite, hybrid alkaline and alkaline cements are the objects of that line of research (1012). Alkaline ( $0 \%$ Portland clinker) cements have attracted and continue to attract considerable attention in the twenty-first century. Such materials are excellent binders and have been heralded as potentially a low-carbon cementitious materials $(13,14)$. A number of authors have reported better mechanical performance at high temperatures in alkaline cements than in OPC (15-18). Alkaline cements based on activated fly ash have been observed to behave pseudo-plastically when loaded $(19,20)$ at temperatures ranging from $500{ }^{\circ} \mathrm{C}$ to $700{ }^{\circ} \mathrm{C}$, with stress-induced softening and considerable strain. Such behaviour also affects residual strength after the material is exposed to high temperatures, with compressive strength values rising as a rule and bending strength declining for reasons of dimensional stability.

Hybrid alkaline cements (HYCs) are a new group of cements, developed by combining knowledge of traditional Portland and alkaline cement chemistry $(11,20-24)$. They are characterised by low clinker content (20\% to $30 \%)$ and a high proportion of supplementary cementitious materials (SCMs). Raising the SCM content to above a certain value $(\sim 35 \%)$ to the detriment of Portland clinker in traditional cements may prompt a significant decline in early age mechanical strength. To elude that effect while increasing the fraction of SCMs to $70 \%$ or $80 \%$, a solid or liquid alkaline activator is added. The inclusion of alkaline activators raises the $\mathrm{pH}$ of the aqueous phase and lowers $\mathrm{Ca}(\mathrm{OH})_{2}$ solubility, partially hastening alite hydration (22), while at the same time expediting the initial SCM reaction (24). Accelerating the hydration reactions of both OPC and SCMs shortens setting times and improves early age mechanical strength. Solid alkaline activators (including $\mathrm{NaOH}, \mathrm{Na}_{2} \mathrm{SiO}_{3}, \mathrm{Na}_{2} \mathrm{SO}_{4}, \mathrm{NaCO}_{3} \ldots$ ) can be used in hybrid alkaline cements. When in contact with the $\mathrm{Ca}(\mathrm{OH})_{2}$ generated by Portland clinker hydration, these salts release $\mathrm{NaOH}$. As a result, only water needs to be added to hydrate the blend (23). The development of 'just add water' binders was a major milestone in HYC industrialisation and commercialisation. The need to add water only constitutes an advantage over traditional alkaline cements, which generally require a highly alkaline, normally viscous, unwieldy solution that is costly to ship and calls for pre-curing at temperatures of $65^{\circ} \mathrm{C}$ to $85^{\circ} \mathrm{C}(25)$.

The main reaction product formed in OPC is a calcium silicate hydrate (C-S-H gel), which may also take up aluminium in its structure (C-(A)$\mathrm{S}-\mathrm{H}$ gel) (26). In aluminosilicate-based alkaline cements (materials with a low calcium content such as fly ash), the main product is an alkaline aluminosilicate hydrate (N-A-S-H gel). Hybrid alkaline cement hydration generates a complex mix of gels, $(\mathrm{C}, \mathrm{N})-\mathrm{A}-\mathrm{S}-\mathrm{H}$ and $\mathrm{N}-(\mathrm{C})-\mathrm{A}-\mathrm{S}-\mathrm{H}$, that eventually evolves into a more thermodynamically stable C-A-S-H gel $(11,27)$.

The aim of this study was to analyse the hightemperature mechanical behaviour of a hybrid alkaline cement, a feature that may be of considerable interest for future eco-cement users. More specifically, it explored a pre-industrially produced HYC comprising $30 \%$ Portland cement clinker and $70 \%$ of a blend of ground granulated blast furnace slag (GGBFS) + fly ash (FA) + solid activator (23).

The high-temperature performance of this cement was assessed during (DT) and after (AT) thermal treatment to determine its 'during exposure' behaviour and its residual strength. The first series 
involved determining compressive and three-point bending strength, modulus of elasticity and fracture toughness (with an innovative notching method) during heating, whilst the second series was conducted on specimens allowed to cool after $2 \mathrm{~h}$ of thermal treatment.

\section{EXPERIMENTAL}

\subsection{Materials}

The two materials analysed in this study were CEM I 42.5 R commercial Portland cement (OPC, the reference) and a new pre-industrial hybrid alkaline cement (HYC). The latter comprised $30 \%$ portland clinker (OPC) $+32.5 \%$ ground granulated blast furnace slag (GGBFS) $+32.5 \%$ fly ash (FA) $+5 \%$ solid activator. Further details on this hybrid cement were described in an earlier paper by the authors (23).

The (Bruker S8 TIGER) X-ray fluorescencedetermined chemical composition of the two cements is given in Table 1. The HYC had a lower $\mathrm{CaO}$ and a higher $\mathrm{SiO}_{2}+\mathrm{Al}_{2} \mathrm{O}_{3}$ content than the OPC. The mineral composition of the cements found on a Bruker AXS D8 ADVANCE X-ray diffractometer was quantified with the Rietveld refinement method. Use of $30 \% \mathrm{Al}_{2} \mathrm{O}_{3}$, corundum (29) as an external standard and TOPAS software for quantification yielded the results listed in Table 2 . The large amorphous fraction in HYC was primarily attributable to the presence of GGBFS and FA.

The particle size of the cements was determined on a SYMPATEC laser diffractometer featuring a measuring range of $0.90 \mu \mathrm{m}$ to $175 \mu \mathrm{m}$. The cement powder was mixed with isopropyl alcohol to eliminate inter-particle electrostatic and Van der Waals forces. The findings graphed in Figure 1 show that the particle size distribution was similar in the two cements, with around $40 \%$ under 10 microns and small differences beyond that value. More specifically, the OPC had a larger percentage of particles $>45 \mu \mathrm{m}$ than the HYC.

The cements were mixed with distilled water at a $1 / \mathrm{s}$ ratio of 0.3 by weight and pre-cured at ambient temperature $\left(25 \pm 1{ }^{\circ} \mathrm{C}\right)$ and $99 \%$ relative humidity for $20 \mathrm{~h}$ in stainless steel moulds. After removal from the moulds they were stored in a controlled humidity chamber (99\%) for $28 \mathrm{~d}$, when they were tested to determine their high-temperature behaviour during (hereafter DT) and after (hereafter AT) thermal treatment.

\subsection{High temperature tests}

Three tests were conducted to determine the hightemperature performance during thermal treatment (DT) of the hardened pastes: compressive and threepoint bending strength and three-point bending fracture toughness. To ensure sample uniformity, the cements were moulded into $100 \times 100 \times 6 \mathrm{~mm}^{3}$ blocks, which were then sliced into specimens of different sizes for the various tests.

The DT mechanical strength tests were conducted on an Instron 3369 test frame in a small, digitally controlled high-temperature furnace. The specimens were heated under a constant load (to avoid load increases due to expansion in the loading system) at a rate of $5{ }^{\circ} \mathrm{C} / \mathrm{min}$ up to $200{ }^{\circ} \mathrm{C}$ and subsequently at $10^{\circ} \mathrm{C} / \mathrm{min}(28,29)$. The low initial heating rate aimed to prevent premature failure caused by initial temperature gradients and early water loss. Specimens were held at the target temperature for 20 min for stabilisation prior to testing.

The specimens used in each test are described below:

TABLE 1. XRF-determined chemical composition (expressed as oxides in wt \%) of the starting materials

\begin{tabular}{lccccccccccc}
\hline & $\mathbf{C a O}$ & $\mathbf{S i O}_{2}$ & $\mathbf{A l}_{2} \mathbf{O}_{3}$ & $\mathbf{F e}_{2} \mathbf{O}_{3}$ & $\mathbf{M g O}$ & $\mathbf{S O}_{3}$ & $\mathbf{N a}_{2} \mathbf{O}$ & $\mathbf{K}_{2} \mathbf{O}$ & $\mathbf{T i O}_{2}$ & $\mathbf{O t h e r}$ & ${ }^{3} \mathbf{L o I}$ \\
\hline${ }^{1} \mathbf{H Y C}$ & 39.67 & 32.53 & 12.2 & 3.83 & 0.94 & 3.12 & 1.04 & 0.78 & 0.5 & 3.07 & 2.32 \\
${ }^{2} \mathbf{O P C}$ & 62.52 & 19.50 & 5.60 & 2.31 & 0.77 & 3.33 & 0.05 & 1.03 & 0.24 & 1.56 & 3.09 \\
\hline
\end{tabular}

${ }^{1} \mathrm{HYC}=$ pre-industrially manufactured hybrid cement.

${ }^{2} \mathrm{OPC}=$ CEM I 42.5R Portland cement supplied by Valderrivas, Spain.

${ }^{3} \mathrm{Lol}$, loss on ignition $\left(1000^{\circ} \mathrm{C}\right)$.

TABLE 2. Rietveld quantification of cement mineralogy (external standard: $30 \% \mathrm{Al}_{2} \mathrm{O}_{3}$ )

\begin{tabular}{|c|c|c|c|c|c|c|c|c|c|c|}
\hline & $\mathrm{C}_{3} \mathrm{~S}$ & $\mathrm{C}_{2} \mathrm{~S}$ & $\mathrm{C}_{3} \mathrm{~A}$ & $\mathrm{C}_{3} \mathrm{AF}$ & Limestone & $\begin{array}{c}\text { Gypsum } \\
\text { /basanite }\end{array}$ & Activator & Quartz & Mullite & Amorphous \\
\hline HYC & ${ }^{1} 20.05$ & ${ }^{1} 5.45$ & ${ }^{1} 3.98$ & ${ }^{1} 3.02$ & & ${ }^{2} 1.70$ & ${ }^{2} 2.03$ & ${ }^{2} 3.00$ & ${ }^{2} 6.27$ & ${ }^{2} 54.5$ \\
\hline OPC & 66.65 & 11.64 & 10.43 & 6.79 & 3.05 & $3.46 / 0.34$ & 1 & I & I & 1 \\
\hline
\end{tabular}

${ }^{1}$ The clinker content in the pre-industrial hybrid cement appeared to be slightly higher than stipulated (on the order of $32.5 \%$ rather than the $30 \%$ specified) (23).

${ }^{2}$ The supplementary cementitious material content $($ GGBFS+FA+Gypsum+ activator $=67.5)$ was somewhat lower than stipulated, due to dosing problems arising under real conditions. 

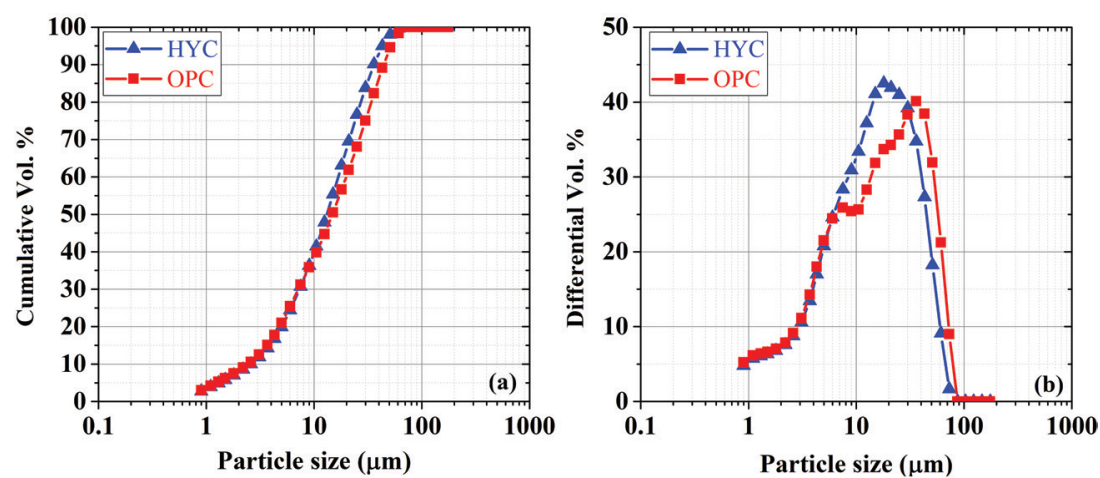

FIgURE 1. Particle size distribution in cement HYC and OPC: (a) cumulative volume; (b) differential volume.
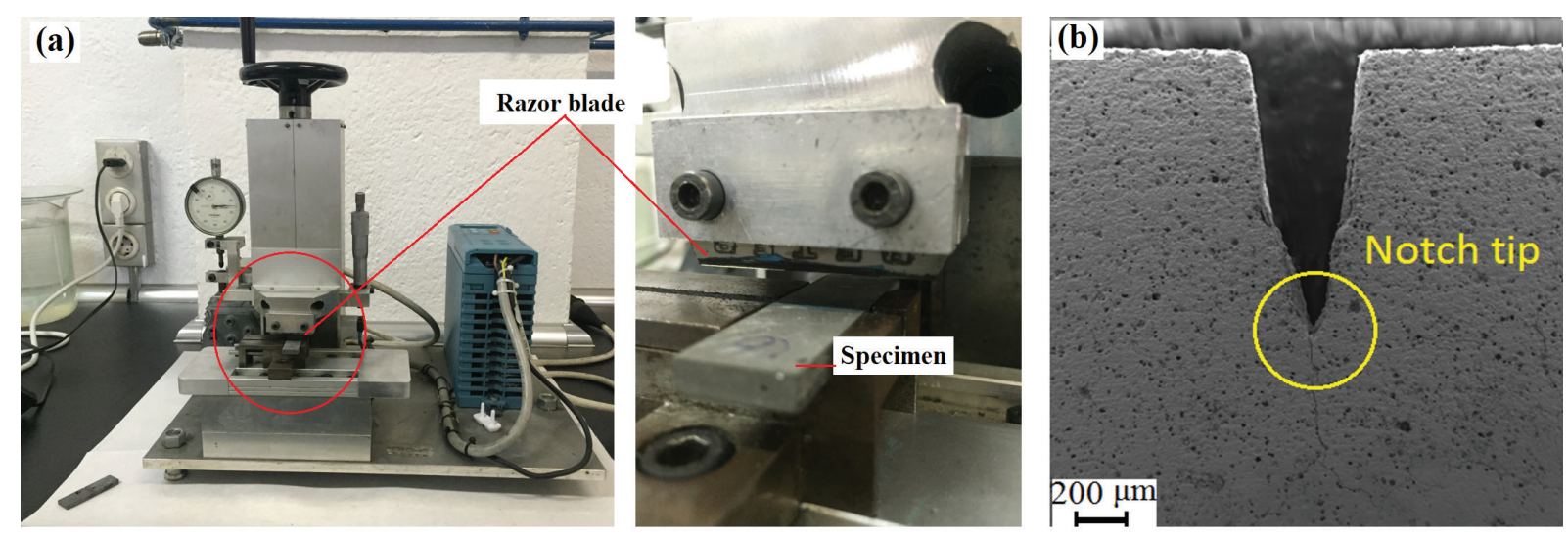

FIGURE 2. (a) Notching apparatus; (b) micrograph of notched specimen.

- The mechanised $\left(4 \times 4 \times 14 \mathrm{~mm}^{3}\right)$ prismatic specimens used to test for compressive strength were pre-loaded at $5.00 \pm 0.01 \mathrm{~N}$ during heating prior to final testing to secure them to the test frame. The target temperatures defined for the DT tests were $25 \pm 2{ }^{\circ} \mathrm{C}$ (ambient), $400{ }^{\circ} \mathrm{C}, 600{ }^{\circ} \mathrm{C}, 800{ }^{\circ} \mathrm{C}$ and $1000^{\circ} \mathrm{C}$.

- Non-standard three-point bending (TPB) tests were conducted on rectangular $\left(4 \times 14 \times 50 \mathrm{~mm}^{3}\right)$ specimens. The samples were pre-loaded at $3.00 \pm 0.01 \mathrm{~N}$ during heating before high-temperature testing. The supports were spaced at $20 \mathrm{~mm}$ and failure stress was found by applying the Benoulli theorem (30). Elastic modulus was calculated from the slope on the stress-strain curves graphed during the TPB tests at target temperatures of $25^{\circ} \mathrm{C}, 200{ }^{\circ} \mathrm{C}, 400{ }^{\circ} \mathrm{C}$ and $600^{\circ} \mathrm{C}$.

- Fracture toughness was found on samples prepared to the single edge V-notched beam (SEVNB) method, using a (very sharp) $150 \mu \mathrm{m}$ thick razor blade coated with $1 \mu \mathrm{m}$ grain diamond paste. This friction-mediated wearing procedure cut a very narrow notch (with a radius of around $10 \mu \mathrm{m}$ at the tip) in the specimen (31). Although to the authors' knowledge there are no earlier references to the application of this advanced method to hardened cement, it has significant potential advantages over known procedures $(32,33)$.

The notching machine designed is depicted in Figure 2(a). The $4 \times 14 \times 50 \mathrm{~mm}^{3}$ paste specimens were secured to adjustable housing underneath the razor blade, in turn set in a holder normal to the length of the specimen. The specimen was moved linearly in the horizontal direction at a strictly controlled frequency while the blade cut the specimen in the vertical direction (likewise adjustable as required). During notching, the diamond powder in the gel sharpened the steel blade and wore down the cement, yielding a tip radius of just a few microns. The conditions needed to cut a notch with a $10 \mu \mathrm{m}$ tip (Figure 2(b)) were defined after detailed and rigorous analysis. The notches generated with this controlled procedure were practically identical to real cracks, delivering a fracture toughness measurement much closer to the real value for the material and eluding possible size effects due to larger notch tip radii and limiting the damage to the notched materials. Microcracks often appear in the material when more aggressive notching systems such as diamond disc or thread systems are used. 
The notched samples were then positioned on the bending strength test frame described above. The supports were again spaced at $20 \mathrm{~mm}$ and the testing rate was $100 \mu \mathrm{m} / \mathrm{min}$. After the test, the failure surfaces were spattered with high-grade gold and analysed under a JEOL JSM 6300 scanning electron microscope.

To determine the behaviour after the thermal treatment (AT), the hardened cement paste was studied for AT mechanical behaviour on $10 \times 10 \times 60 \mathrm{~mm}^{3}$ prismatic specimens prepared as described above. The $28 \mathrm{~d}$ specimens were measured and weighed prior to thermal treatment. After treatment for $2 \mathrm{~h}$ in a furnace pre-heated to a target temperature of $400{ }^{\circ} \mathrm{C}, 600{ }^{\circ} \mathrm{C}, 800{ }^{\circ} \mathrm{C}$ or $1000^{\circ} \mathrm{C}$ the samples were set on ceramic plates and allowed to gradually cool for at least $12 \mathrm{~h}$. They were then tested for mechanical behaviour, including bending strength and fracture toughness. The relative mechanical strengths were defined as $\sigma_{\mathrm{R}}=\sigma / \sigma_{25}$, where $\sigma_{25}$ is strength at the reference temperature.

Post thermal treatment porosity was found on a Micromeritics AutoPore IV 9500 mercury intrusion porosimeter, featuring a maximum pressure of $227 \mathrm{MPa}$ at a contact angle of $141.3^{\circ}$ and a surface tension of 485 dynes/cm (34). The untreated $28 \mathrm{~d}$ pastes were also ground to powder for thermogravimetric/differential thermal analysis (TG/DTA) on a Labsys SETARAM analyser, in which the air temperature was ramped up from $25^{\circ} \mathrm{C}$ to $1000{ }^{\circ} \mathrm{C}$ at a rate of $10^{\circ} \mathrm{C} / \mathrm{min}$.

\section{RESULTS}

\subsection{TG and DTA}

The TG and DTA curves for the $28 \mathrm{~d} \mathrm{OPC}$ and HYC pastes are plotted in Figure 3. The endothermal peaks between $50{ }^{\circ} \mathrm{C}$ and $150{ }^{\circ} \mathrm{C}$ observed on both curves $(3-5,35)$ were associated with the loss of unbound water and water in the hydrated phases. In OPC the peak at $50{ }^{\circ} \mathrm{C}$ to $200{ }^{\circ} \mathrm{C}$ was related primarily to the loss of water from ettringite and the C-S-H phases, as well as of unbound water. Mass loss at $200{ }^{\circ} \mathrm{C}$ was greater in OPC (11\%) than in HYC (9\%). The difference may be attributed to the formation of a smaller amount of hydrates in the HYC, particularly AFm and AFt phases and of hydrates with less water in their structure. C-S-H gels are deemed to take up more water in their structure than C-A-S-H or N-A-S-H gels (24). The endothermal peak at $430{ }^{\circ} \mathrm{C}$ to $450{ }^{\circ} \mathrm{C}$ related to portlandite dehydroxylation $(1,3)$ was much more intense in OPC than in HYC (Figure 3), an indication that more portlandite formed in the former than in the latter. A small peak at temperatures of around $670{ }^{\circ} \mathrm{C}$ was associated with $\mathrm{CaCO}_{3}$ decarbonation (36).

\subsection{Mechanical behaviour during thermal treatment}

The DT compressive strength findings are shown in Figure 4. At ambient temperature, OPC exhibited higher compressive strength than HYC. When the temperature rose to $400{ }^{\circ} \mathrm{C}$, OPC strength declined steeply from $110 \mathrm{MPa}$ to $80 \mathrm{MPa}$, whereas in HYC

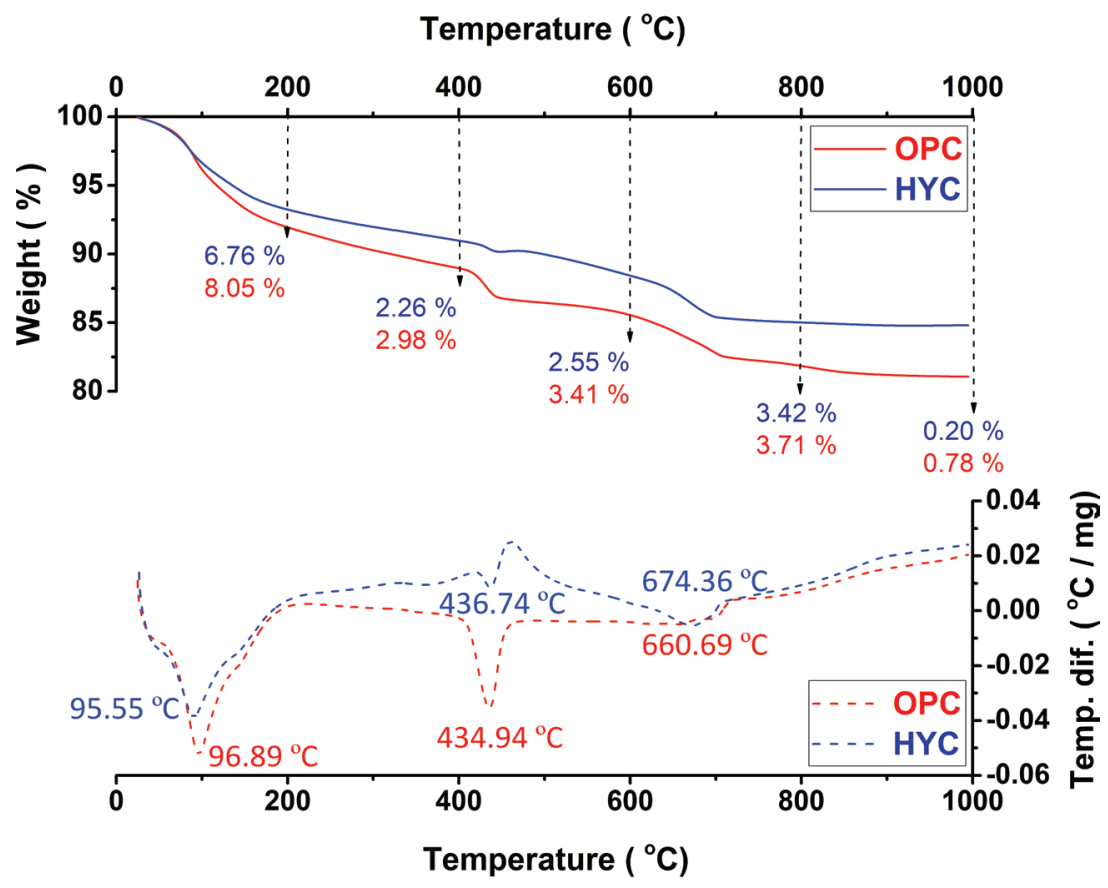

FIgURE 3. TG-DTA data for $28 \mathrm{~d}$ OPC and HYC. 
the drop was more moderate, from $86 \mathrm{MPa}$ to $76 \mathrm{MPa}$. At temperatures of over $400{ }^{\circ} \mathrm{C}$, compressive strength declined similarly in the two materials, sliding linearly to $800{ }^{\circ} \mathrm{C}$. At that and higher temperatures, OPC compressive strength was practically nil. In contrast, HYC retained a certain residual strength at $800{ }^{\circ} \mathrm{C}$, which did not decline

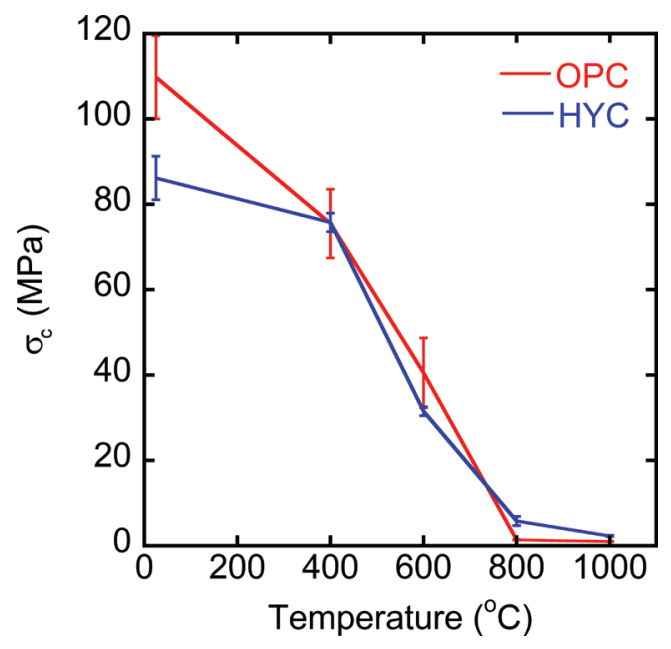

Figure 4. Variation in mean compressive strength with temperature in DT tests (the bars denote the mean quadratic error for each data point). to naught as in OPC until the temperature reached $1000{ }^{\circ} \mathrm{C}$. The inference is that HYC performs better than OPC in structural applications exposed to high-temperature compressive stress.

Figure 5 shows the stress-strain curves plotted with DT compressive strength test data. The elastic limit was determined assuming a $0.2 \%$ deviation in the stress-strain curves, drawing a line parallel to the initial part of the curve where the materials exhibited plastic behaviour. That method delimits the elastic zone, although it is only applicable when materials exhibit plastic behaviour at high temperatures. At $25^{\circ} \mathrm{C}, 400{ }^{\circ} \mathrm{C}$ and $600{ }^{\circ} \mathrm{C}$, OPC showed insignificant non-linear strain and brittle failure in the DT compression tests. HYC exhibited similar brittle failure, but only up to $400{ }^{\circ} \mathrm{C}$ (Figure 5(c)). At $600{ }^{\circ} \mathrm{C}$, the stress-strain curve for HYC exhibited non-linear strain compatible with macroscopic and microstructural scale plastic strain prior to failure. After exposure to $800{ }^{\circ} \mathrm{C}$, OPC and HYC showed ductile failure with substantial plastic strain. In parallel, yield stress declined sharply with rising temperatures, with the appearance of non-linear strain. HYC had a slightly higher yield stress than OPC (compare Figures 5(b) and 5(d)). Consequently, HYC would out-perform OPC in structural applications exposed to high-temperature bending, as in those exposed to compressive stress.
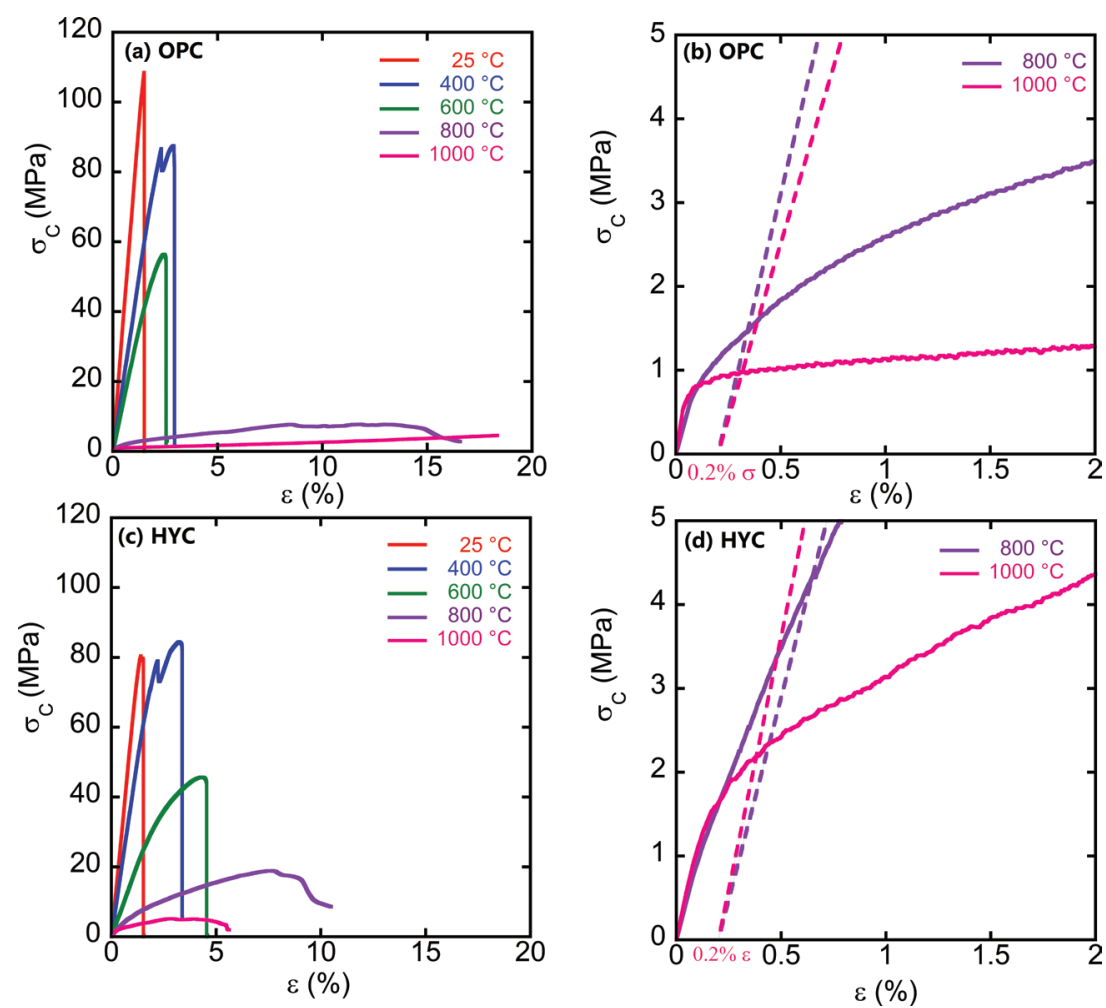

FIGURE 5. Stress-strain curves plotted during thermal treatment at different temperatures for (a) OPC, (b) HYC; and enlargement of stress-strain curves for (c) OPC and (d) HYC at $800^{\circ} \mathrm{C}$ and $1000^{\circ} \mathrm{C}$ (although in this test at least three samples were analysed at each temperature, only one curve per temperature is shown by way of reference). 

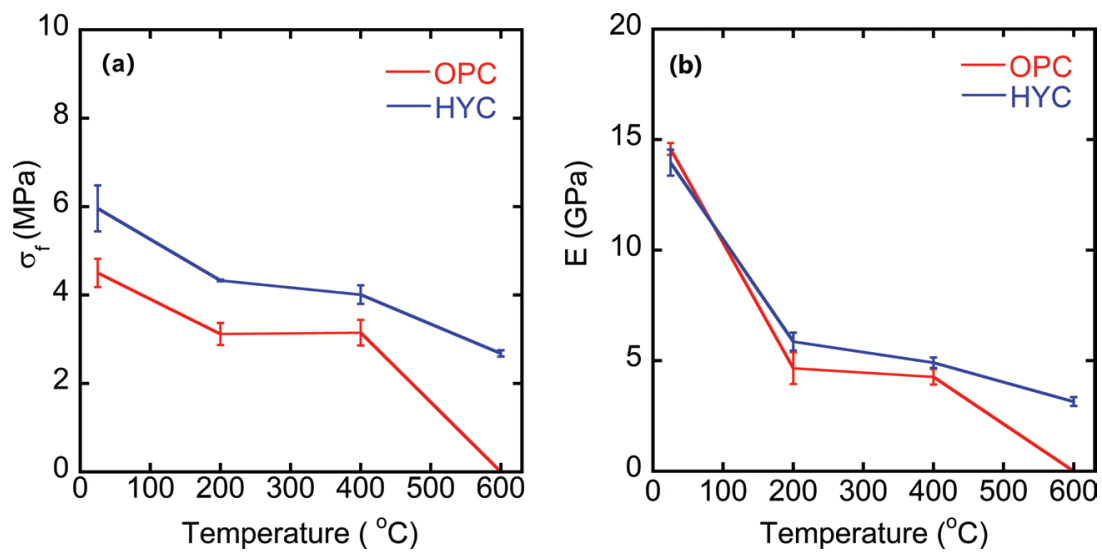

FIGURE 6 Variation in (a) bending stress and (b) elastic modulus with temperature in $4 \times 14 \times 5 \mathrm{~mm}^{3}$ OPC and HYC paste specimens (the bars denote the mean quadratic error for each data point).
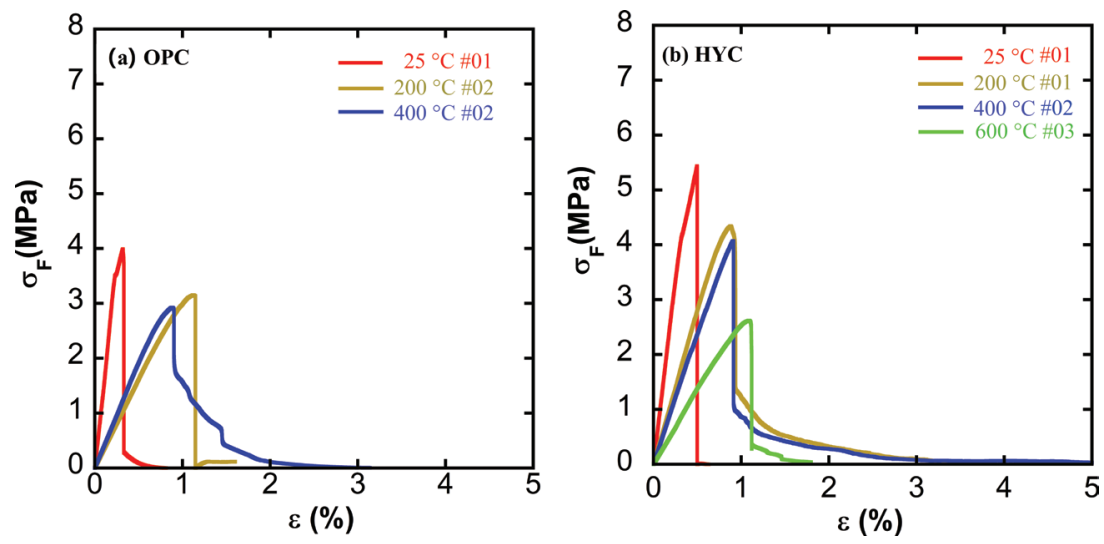

FIGURE 7. Stress-strain curves at several temperatures based on DT bending strength tests for: a) OPC; and b) HYC. Note: although in this test at least three samples were analysed at each temperature, only one curve per temperature is shown by way of reference.

DT bending strength is given for OPC and HYC in Figure 6(a). Conversely to compressive strength, at ambient temperature bending strength was $(40 \%)$ higher in HYC than in OPC. Since the decline in bending strength with rising temperature was similar in the two materials, the difference remained constant up to $600{ }^{\circ} \mathrm{C}$, where it widened.

Since at $600^{\circ} \mathrm{C}$ the OPC samples collapsed before the test began, their value could not be determined. Rather, as the minor load applied during heating sufficed to cause the sample to fail before reaching $600{ }^{\circ} \mathrm{C}$, strength was deemed to be nil at that temperature. In these tests, HYC clearly performed better than OPC.

The modulus of elasticity (E) (found with the linear section of the stress-strain curve) for the two materials at different temperatures is graphed in Figure $6(\mathrm{~b})$. In the $25^{\circ} \mathrm{C}$ to $200{ }^{\circ} \mathrm{C}$ range, E declined very significantly in both materials, to slightly over a third of the initial value. Nonetheless, with a decline of $58 \%$ HYC performed somewhat better than OPC, which dipped by $68 \%$. From $200{ }^{\circ} \mathrm{C}$ to $400{ }^{\circ} \mathrm{C}$ the values continued to drop, but more moderately. At $600{ }^{\circ} \mathrm{C}$ the
OPC modulus was deemed to be zero, given the structural disintegration of the material, whereas in HYC the elastic modulus continued to decline gradually with rising temperature. The hybrid cement exhibited higher E values than Portland cement at all the temperatures tested.

The DT stress-strain curves plotted with bending stress data for the cements at $25^{\circ} \mathrm{C}, 200{ }^{\circ} \mathrm{C}$ and $400{ }^{\circ} \mathrm{C}$ are shown in Figure 7 . Initially the OPC exhibited elastic and linear behaviour denoting no cracking (37), followed by a brief non-linear stage prior to reaching the yield load that triggered abrupt failure. In this final stage micro-cracks appeared and cracks of a critical size propagated (similar observations have been reported in the literature (38-41). Oddly, both materials exhibited this dual behaviour at all test temperatures. It was more visible with rising temperatures, however, particularly after $400{ }^{\circ} \mathrm{C}$ for OPC and $600{ }^{\circ} \mathrm{C}$ for HYC. The non-linear part of the stress-strain curve for the two materials denoted the appearance of fracture and plasticity that conditioned material deterioration and failure. An analysis of the different types of curves for the two materials revealed that they were consistent 
with the declines observed in bending strength and modulus of elasticity with rising temperature.

Fracture strength, $\mathrm{KI}_{\mathrm{C}}$, defines the critical stress needed for a crack to propagate catastrophically inside a material, in which the subscript $I C$ denotes the intensity factor for critical stress $K$ in fracture mode $I$ at the tip of the crack (40-43).

The small size of the furnace and sample preparation limitations imposed the use of non-standard $50 \times 14 \times 4 \mathrm{~mm}^{3}$ specimens and $20 \mathrm{~mm}$ spacing between supports in this experiment. Although international standards on fracture toughness tests call for a span/ depth ratio of 4 (40-43) and a notch length of $50 \%$ of the depth, the conditions used here (span/depth ratio of 5 and crack length $37.5 \%$ of the depth) could be deemed valid. $\mathrm{K}_{\mathrm{IC}}$ was calculated with the expressions proposed by Guinea et al. (44), in which the stress intensity factor can be applied irrespective of the crack/depth ratio and for span/depth ratios of over 2.5.

The $\mathrm{K}_{\mathrm{IC}}$ values are plotted against temperature for the two pastes in Figure 8. The low $\mathrm{K}_{\mathrm{IC}}$ values observed were expected given the brittle nature of

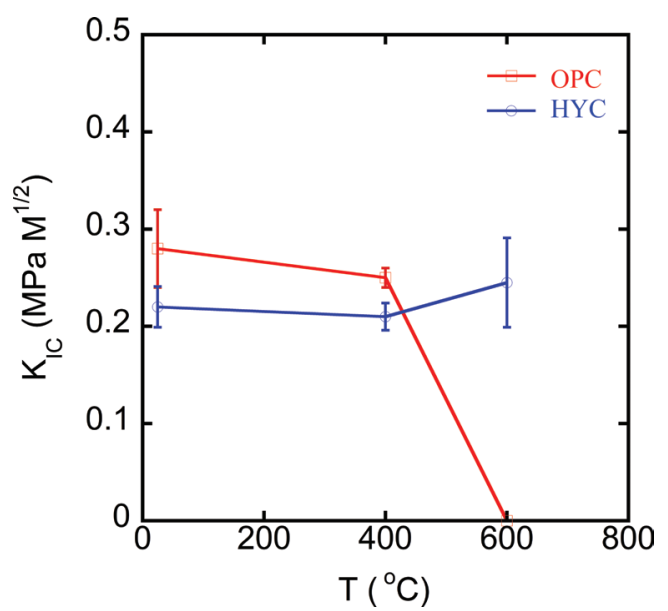

FIGURE 8. Variation in fracture toughness with temperature (the bars denote the mean quadratic error for each data point). the materials. The values were slightly higher in OPC than in HYC at temperatures of $25^{\circ} \mathrm{C}$ to $400{ }^{\circ} \mathrm{C}$. At $600^{\circ} \mathrm{C}$ the OPC disintegrated and could not be tested, whereas $\mathrm{K}_{\mathrm{IC}}$ rose perceptibly in HYC at that temperature. The DT data fracture toughness curves for the two materials are plotted in Figure 9. Both pastes exhibited linear elastic behaviour, validating the use of the aforementioned equations. In this respect also, HYC out-performed OPC at high temperatures.

\subsection{After treatment mechanical strength}

Sample residual compressive and bending strength values after $2 \mathrm{~h}$ of high-temperature exposure are shown in Figure 10. Strength was observed to decline significantly after exposure to just $400{ }^{\circ} \mathrm{C}$, although the pattern differed depending on the cement.

In OPC, residual compressive strength dropped linearly with rising temperature, to a mere $20 \%$ of the initial value at $1000^{\circ} \mathrm{C}$. Bending strength in this material behaved very differently, sliding intensely at $400{ }^{\circ} \mathrm{C}$ (to $20 \%$ of the initial value) with no further decline at higher temperatures.

Mechanical strength in HYC exhibited unique behaviour. Compressive strength followed a pattern similar to the findings for OPC although the decline was less intense, to $30 \%$ of the initial value at $1000{ }^{\circ} \mathrm{C}$. Bending stress also declined significantly less and more gradually across the entire range of temperatures. The most prominent finding was the very visible rise in the mechanical strength between $400{ }^{\circ} \mathrm{C}$ and $600^{\circ} \mathrm{C}$, to nearly the ambient temperature value at $600{ }^{\circ} \mathrm{C}$. The appearance of that peak in both types of strength and for repeated specimens ruled out possible experimental error.

\subsection{Porosity}

Total porosity and variation in pore size distribution in samples heated to different temperatures are shown in Figure 11. Cement paste pore size is
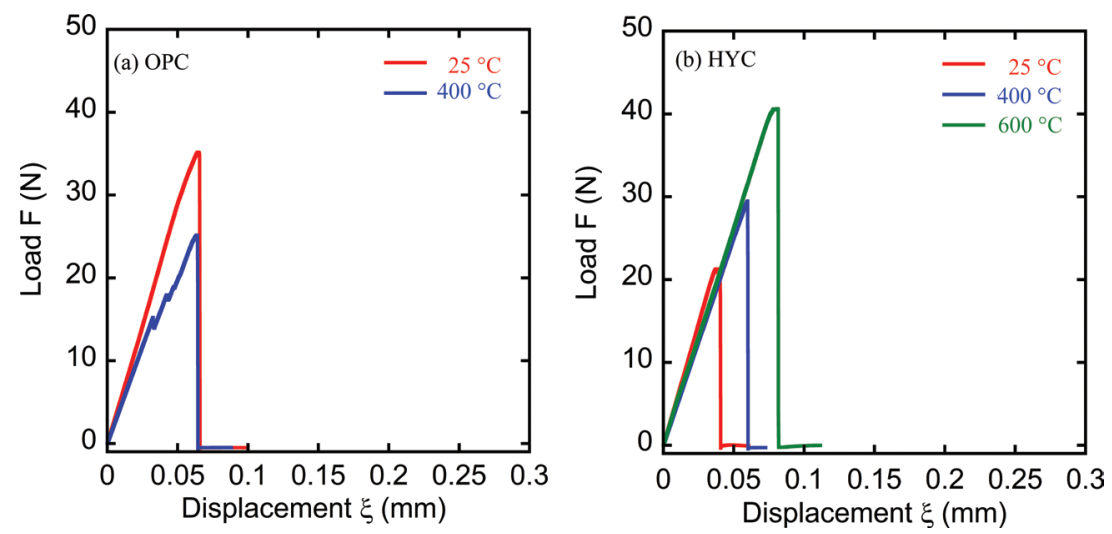

FIGURE 9. Examples of displacement-load curves at different temperatures based on DT fracture toughness tests for: (a) OPC and (b) HYC. 

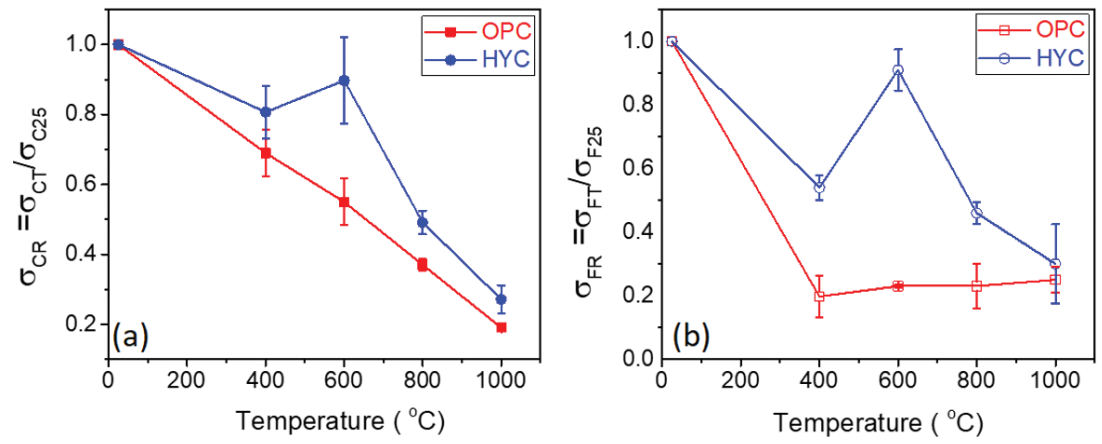

FIGURE 10. Residual strength after $2 \mathrm{~h}$ of exposure to different temperatures: (a) compressive strength; (b) bending strength (the bars denote the mean quadratic error for each data point).

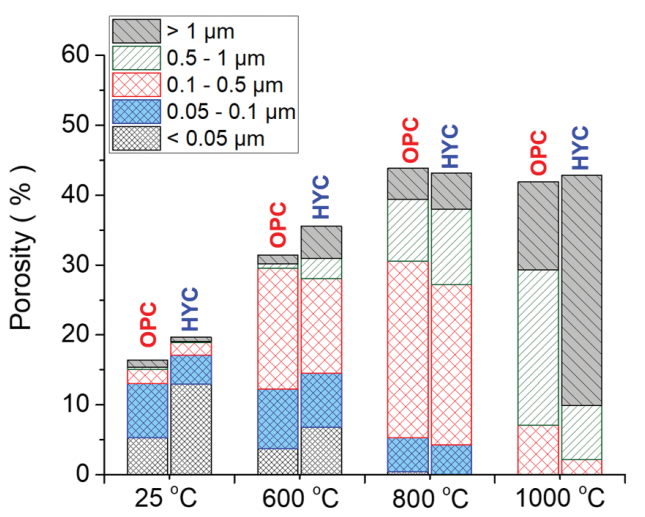

FIGURE 11. Variation in total porosity and pore size distribution with temperature in OPC and HYC.

typically classified into four fractions (45): i) $<0.1 \mu \mathrm{m}$, associated with hydrated phase porosity; ii) $0.1 \mu \mathrm{m}$ to $0.5 \mu \mathrm{m}$, with medium-sized capillary pores; iii) $0.5 \mu \mathrm{m}$ to $1 \mu \mathrm{m}$, with large capillary pores; and iv) $>1 \mu \mathrm{m}$, with large capillary pores with entrained air.

In this study, high-temperature exposure had a significant impact on pore size distribution and total porosity, primarily in the $0.05 \mu \mathrm{m}$ to $1 \mu \mathrm{m}$ and $>1 \mu \mathrm{m}$ fractions, changes that affect material mechanical strength and permeability in particular. At ambient temperature HYC exhibited higher initial porosity than OPC, although with a larger percentage of small pores, which might explain its higher bending strength. As the figure shows, the overall trend was for a rise in porosity with temperature, which was steeper in OPC than HYC. Porosity rose by over $100 \%$ in both materials after exposure to $800{ }^{\circ} \mathrm{C}$ or higher.

Pore size distribution was observed to vary with temperature as follows:

i) The percentage of pores under $0.05 \mu \mathrm{m}$ declined with rising temperature in both cements, with the fraction practically disappearing at $800^{\circ} \mathrm{C}$.

ii) High-temperature exposure induced a drastic increase in pore size, with the smallest pores disappearing altogether at $1000^{\circ} \mathrm{C}$. iii) The increase in total porosity was due to the rise in pores of over $0.1 \mu \mathrm{m}$, which may be deemed a critical defect size able to trigger material fracture.

iv) Temperature had a generally significant effect on pore size distribution with a substantial change in cement paste microstructure after long ( 2 h) exposure.

\subsection{SEM findings}

The experimental findings described in this article show that hybrid alkaline cement exhibited generally higher mechanical strength and toughness than OPC in nearly all the high temperature situations analysed. Performance declined steeply with temperature in both materials, indicating that their microstructures underwent physical-chemical change that conditioned their mechanical behaviour. The fracture surfaces were examined under SEM to validate that hypothesis.

The resulting micrographs are reproduced in Figure 12 . At $25^{\circ} \mathrm{C}$, the OPC paste had a typically compact structure with no visible surface cracks. In contrast the HYC paste contained a significant fraction of large pores, a finding consistent with the data in Figure 11. In both materials (Figures 12(a) and (d)) fracture was essentially the result of a crack generated around the tip of the notch.

An analysis of crack propagation in the OPC samples exposed to $400{ }^{\circ} \mathrm{C}$ (Figures 12(b) and (c)) revealed general cracking throughout the material in all directions, both on and perpendicular to the fracture plane. That generalised cracking was the cause of the loss of OPC strength at $400{ }^{\circ} \mathrm{C}$ and of its structural integrity at $600{ }^{\circ} \mathrm{C}$ under insignificant loads, as observed in the tests conducted.

As noted, the hybrid cement had a brittle fracture surface similar to that found for OPC, although with larger pores in the matrix, consistent with the MIP results. Nonetheless, at high temperatures (Figures 12(e) and (f)), while the large pores were still present, no clearly identifiable cracks were visible on the HYC fracture surface. 

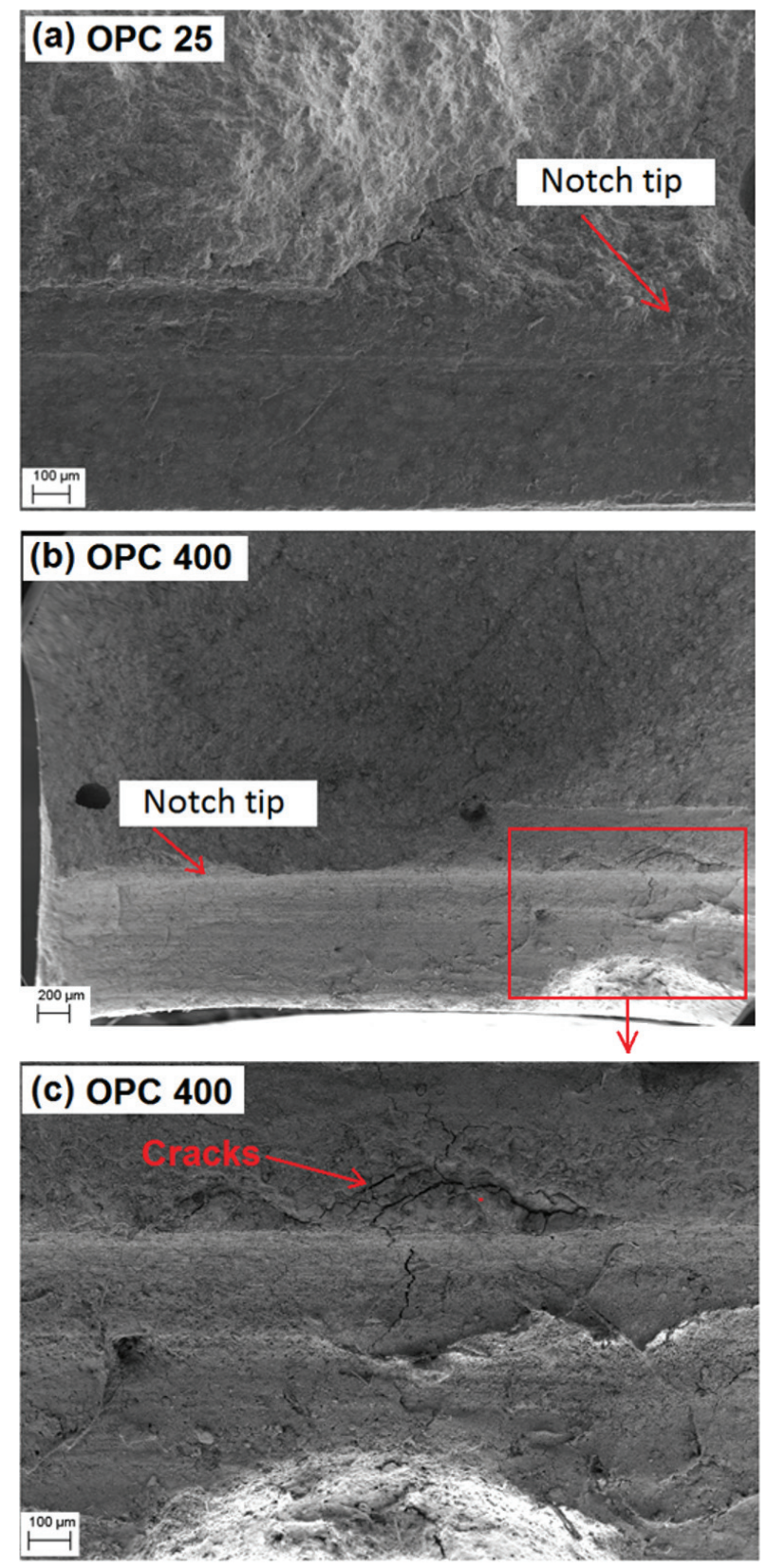
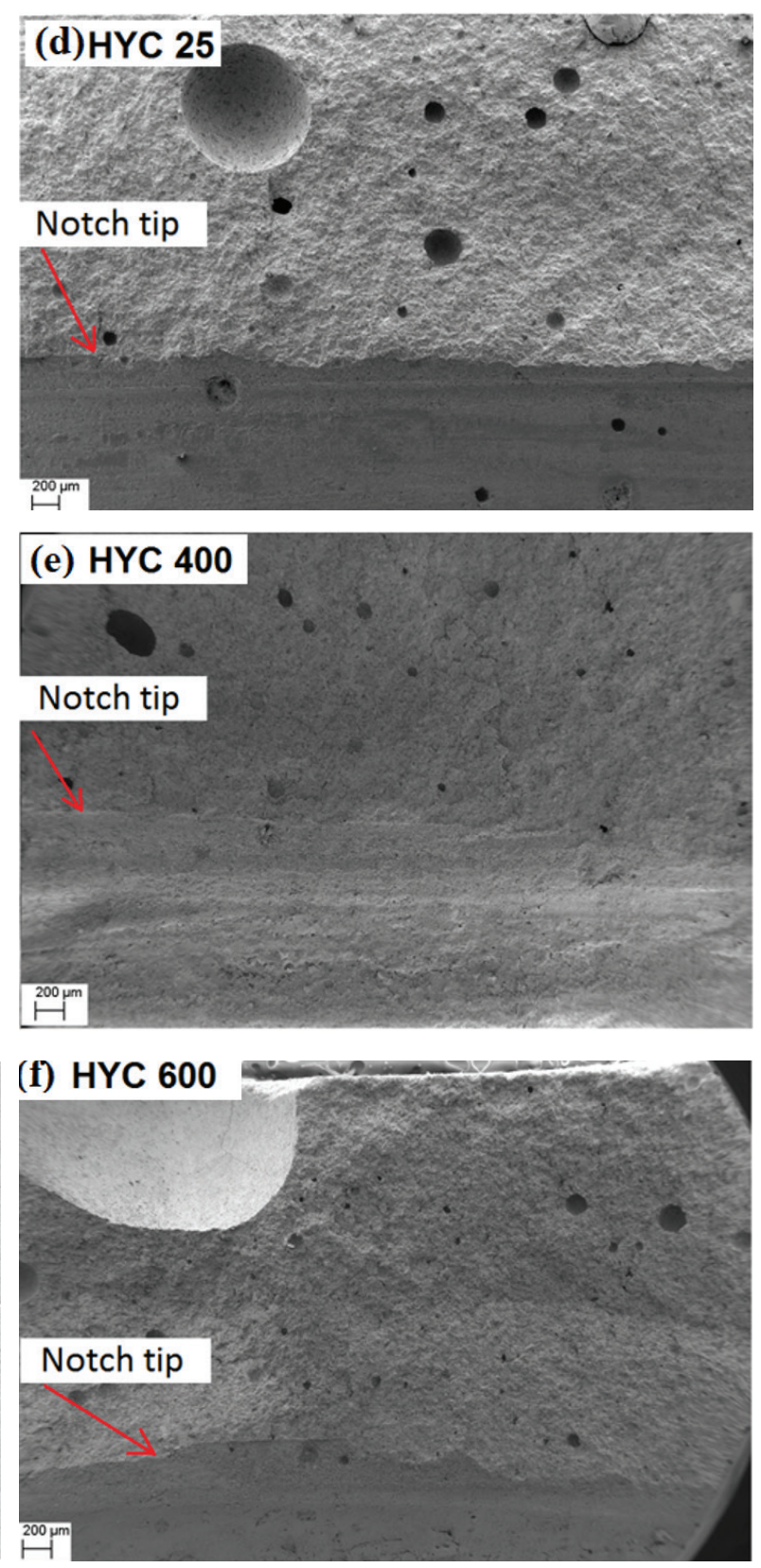

FIGURE 12. Fracture surface after $\mathrm{K}_{\mathrm{IC}}$ testing for OPC and HYC, loaded parallel to the fracture surface.

The very sharp notch tips in both materials were consistently the starting point for fracture, attesting to the validity of the new notching methodology proposed, which generated no flaws or microcracking.

In the $25^{\circ} \mathrm{C}$ to $400{ }^{\circ} \mathrm{C}$ interval the two cements exhibited similar brittle failure with no apparent plastic strain, as well as similar high-temperature mechanical behaviour.

In the DT tests, cracks formed unstably and after extending rapidly under loading, grew spontaneously with no need to raise the load (34). Greater OPC deterioration was nonetheless obviously related to the presence of general cracking in the matrix. OPC paste is known to lose unbound water when heated to temperatures of under $400^{\circ} \mathrm{C}$, along with water bound to AFt- and AFm-type phases and to C-S-H gel. Transport of the resulting water vapour changes the material's microstructure with a decisive effect on its mechanical behaviour. The inference is that cement paste strength declines primarily as a result of the appearance of microcracks generated by the pressure exerted by water vapour against the internal walls of the micropores present throughout the matrix (Figure 11). 


\section{DISCUSSION}

In light of the foregoing, the higher mechanical strength in HYC than in OPC at under $400{ }^{\circ} \mathrm{C}$ can be explained as follows:

i) HYC has a lower water content than OPC (as confirmed by the TG/DTA findings, Figure 3). Studies of hybrid cement mineralogy, micro- and nanostructure have shown the main hydration product to be a mix of C-(A)-S-H and C-A-S-H gels that are more intensely polymerised than traditional C-S-H gel, the product of OPC hydration $(46,47)$. Whilst the water content in such mixed gels has yet to be precisely quantified, the fact that their structure is two-dimensional (48) suggests that it is lower than in C-S-H due to the larger number of $\mathrm{Si}-\mathrm{O}-\mathrm{Si}$ and $\mathrm{Si}-\mathrm{O}-\mathrm{Al}$ bonds (condensation polymerisation). The TG curve in Figure 3 showed less mass loss from $25^{\circ} \mathrm{C}$ to $400^{\circ} \mathrm{C}$ in HYC $(9.02 \%)$ than in OPC $(11.03 \%)$. Although that lower water loss may also be due to a lesser degree of hydration in HYC than OPC, the authors deem that the differences are largely attributable to the lower water content in the highly polymerised gels forming in HYC. More significant dehydration and dehydroxylation (up to $600{ }^{\circ} \mathrm{C}$, see Figure 3, OPC) induced the release of more water vapour under pressure in the OPC sample, causing greater cracking.

ii) The large number of pores in the HYC matrix could provide an escape route for moisture at high temperatures (Figure 11). Whereas lower effective porosity contributes to higher compressive strength, it may also hinder high-temperature water vapour transport, prompting the appearance of more microcracks and material deterioration.

In addition, portlandite dehydration, known to occur at around $435^{\circ} \mathrm{C}$, gives rise to $\mathrm{CaO}$ and water that must be eliminated. Those processes generate pressure inside the matrix that may reduce mechanical strength and induce material collapse. The lower $\mathrm{Ca}(\mathrm{OH})_{2}$ content in the HYC matrix detected by MIP would consequently also contribute to its better mechanical performance at high temperatures.

Mechanical strength declined so drastically in OPC between $400{ }^{\circ} \mathrm{C}$ and $600{ }^{\circ} \mathrm{C}$ that no DT testing could be conducted at the latter temperature due to material disintegration. Further to the above reasoning, that deterioration would be attributable to portlandite dehydration and C-S-H gel decomposition.

The low $\mathrm{Ca}(\mathrm{OH})_{2}$ content in hybrid alkaline cement, in turn, is due to the following:

i) Less portlandite is generated as a hydration product in HYC than in OPC due to the low $(20 \%)$ $\mathrm{C}_{3} \mathrm{~S}$ content in the former (23). ii) Pozzolanic reactions consume the $\mathrm{Ca}(\mathrm{OH})_{2}$ in the hybrid cement system $(49,50)$.

iii) $\mathrm{Ca}(\mathrm{OH})_{2}$ may react with $\mathrm{Na}_{2} \mathrm{SO}_{4}$ (main solid activator used in HYC), generating alkalis in the system. The high alkaline content raises the pore solution $\mathrm{pH}$, favouring $\mathrm{SCM}$ dissolution and the possible precipitation of alkaline reaction products ((N,C)-A-S-H gels) (51).

The better mechanical behaviour of HYC at $600{ }^{\circ} \mathrm{C}$ might be related to the alkaline (sodium), fly ash and in general high amorphous phase content in the matrix (Table 2). In earlier studies, pseudo-viscous phases were observed to form in fly ash-based alkaline cement at around $500{ }^{\circ} \mathrm{C}$ (34). Vitreous transition at $560{ }^{\circ} \mathrm{C}(52)$ and hightemperature softening have also been reported in fly ash alkaline cement (53). In contrast, no macroscopic plastic behaviour was observed in HYC at $600{ }^{\circ} \mathrm{C}$. Nonetheless, a pseudo-viscous phase possibly appearing at around that temperature due to the presence of alkalis and fly ash would affect the pore structure of the matrix, sealing and rounding crack tips and giving rise to local plastic strain in the DT tests. That would provide a simple explanation for the post-treatment residual strength observed at $600{ }^{\circ} \mathrm{C}$, for the rise in local plastic strain might at the same time prompt plastic micro-deformation in the materials and high energy absorption prior to catastrophic failure.

The variation in the elastic modulus with temperature also merits discussion. As Figure 6(b) shows, E declined at $200{ }^{\circ} \mathrm{C}$ much more significantly than at higher temperatures, possibly as a result of water release from the cements during heating prior to reaching $200{ }^{\circ} \mathrm{C}$. Water transport creates micropores, raising total porosity and gradually lowering Elastic modulus. Nonetheless, that rise in micro- and total porosity would not contribute to the loss of bending strength, for whereas rising total porosity induces a decline in the modulus of elasticity (a rough estimate could be found based on the rule of mixtures), mechanical strength is controlled by critical defect size. That value did not vary significantly in the $25^{\circ} \mathrm{C}$ to $200{ }^{\circ} \mathrm{C}$ interval, where the change involved micropore generation and microcracking on a different scale. Since porosity grew more slowly after $200{ }^{\circ} \mathrm{C}$, the decline in the modulus of elasticity was also shallower. Furthermore, $\mathrm{E}$ decreased more rapidly in OPC than in HYC because matrix microcracking was much more intense in the former, where no plastic micro-deformation-related repair mechanisms were present, as explained above.

\section{CONCLUSIONS}

The conclusions that can be drawn from the present study are listed below: 
1. Mechanical strength, fracture toughness and modulus of elasticity measured during thermal treatment declined with rising temperatures.

2. Both during and after thermal treatment, HYC generally out-performed OPC.

3. Cementitious material temperature sensitivity, even at under $200{ }^{\circ} \mathrm{C}$, is primarily associated with water transport, which induces mechanical strength decline, hydrated gel decomposition, $\mathrm{Ca}(\mathrm{OH})_{2}$ dehydroxylation and calcite decomposition in OPC and HYC. Consequently, the relatively low water and $\mathrm{Ca}(\mathrm{OH})_{2}$ content in hybrid cement contributes to its enhanced performance relative to OPC at high-temperatures.

4. The greater non-elastic strain in HYC in the DT mechanical tests at temperatures of over $600{ }^{\circ} \mathrm{C}$ may largely explain the higher mechanical strength and lesser microcracking in $\mathrm{HYC}$ under such conditions.

5. The new single edge V-notched beam (SEVNB) method is applicable to cement pastes, preventing the possible limitations inherent in other methods and affording a fracture toughness measurement closer to the actual value by cutting a notch tip radius of just tens of microns. Nonetheless, low fracture strength values were recorded for both materials. With the experimental methods deployed in this study, HYC performed substantially better than OPC at $600{ }^{\circ} \mathrm{C}$.

6. HYC is a plausible alternative to Portland cement under high temperature conditions, at which it performed better than the traditional material in the various situations analysed in this study.

\section{ACKNOWLEDGEMENTS}

This research was funded by the Spanish Ministry of the Economy, Industry and Competitiveness and ERDF (BIA2016-76466-R and RTC20164872-S), the Spanish Ministry of the Research, Innovation and Universities (MAT2015-70780-C44-P), and the Region of Madrid (S2018/NMT-4411 ADITIMAT-CM: Additive Manufacturing: From Material To Application). Author Dr. Qu Bo benefitted from a China Scholarship Council (CSC) PhD. grant.

\section{REFERENCES}

1. Taylor, H.F.W. (1997) Cement Chemistry, Thomas Telford, London.

2. Schneider, M.; Romer, M.; Tschudin, M.; Bolio, H. (2011) Sustainable cement production-present and future, Cem.Concr.Res. 41 [7] 642-650. https://doi.org/10.1016/j. cemconres.2011.03.019

3. Scrivener, K.; Snellings, R.; Lothenbach, B. (2016) A practical guide to microstructural analysis of cementitious materials, CRC Press, New York.
4. Piasta, J.; Sawicz, Z.; Rudzinski, L. (1984) Changes in the structure of hardened cement paste due to high temperature, Matériaux et Construction, 17, 291-296. https://doi. org/10.1007/BF02479085.

5. Stepkowska, E.; Blanes, J.; Franco, F.; Real, C.; PérezRodriguez, J.; (2004) Phase transformation on heating of an aged cement paste, Thermochim. Acta, 420 [1-2], 79-87. https://doi.org/10.1016/j.tca.2003.11.057

6. Alonso, C.; Fernandez, L. (2004) Dehydration and rehydration processes of cement paste exposed to high-temperature environments, J. Mater. Sci. 39 [9], 3015-3024. https:// doi.org/10.1023/B:JMSC.0000025827.65956.18

7. Handoo, S.K.; Agarwal, S.; Agarwal, S.K. (2002) Physicochemical, mineralogical, and morphological characteristics of concrete exposed to elevated temperatures, Cem.Concr.Res. 32 [7], 1009-1018. https://doi.org/10.1016/ S0008-8846(01)00736-0.

8. Habert, G.; Billard, C.; Rossi, P.; Chen, C.; Roussel, N. (2010) Cement production technology improvement compared to factor 4 objectives, Cem. Concr.Res. 40 [5], 820-826. https://doi.org/10.1016/j.cemconres.2009.09.031.

9. Imbabi, M.S.; Carrigan, C.; McKenna, S.; (2012) Trends and developments in green cement and concrete technology, Int. J. Sustainable Built Environ. 1 [2], 194-216. https:// doi.org/10.1016/j.ijsbe.2013.05.001.

10. Martín-Sedeño, M.C.; Cuberos, A.J.M ; De la Torre, Á.G.; Álvarez-Pinazo, G.; Ordónez, L.M.; Gateshki, M.; Aranda, M.A.G. (2010) Aluminum-rich belite sulfoaluminate cements: Clinkering and early age hydration, Cem. Concr.Res. 40 [3], 359-369. https://doi.org/10.1016/j. cemconres.2009.11.003.

11. Rivera, J.F.; Mejia, J.M.; Mejia de Gutierrez, R.; Gordillo, M. (2014) Hybrid cement based on the alkali activation of by-products of coal, Revista de la Construcción, 13 [2],31-39. http://dx.doi.org/10.4067/S0718-915X2014000200004.

12. Sui, T.; Fan, L.; Wen, Z.; Wang, J.; (2015) Properties of Belite-Rich Portland Cement and Concrete in China, $J$. Civ. Engineering and Architecture, 4, 384-392. http://dx.doi. org/10.17265/1934-7359/2015.04.002

13. Shi. C.; Fernández Jiménez, A.; Palomo A. (2011) New cements for the 21st century: The pursuit of an alternative to Portland cement, Cem.Concr.Res.,41[7]:750-763. https:// doi.org/10.1016/j.cemconres.2011.03.016.

14. Pacheco-Torgal, F.; Castro-Gomes, J.; Jalali, S. (2008) Alkali-activated binders: A review: Part 1 . Historical background, terminology, reaction mechanisms and hydration products, Constr. Build. Mater. 22 [7], 1305-1314. https:// doi.org/10.1016/j.conbuildmat.2007.10.015.

15. Barbosa, V.F.; MacKenzie, K.J. (2003) Thermal behaviour of inorganic geopolymers and composites derived from sodium polysialate, Mater. Res. Bull. 38 [2], 319-331. https://doi.org/10.1016/S0025-5408(02)01022-X.

16. Wang, H. (2008) The effects of elevated temperature on cement paste containing GGBFS, Cem. Concr. Compos. 30 [10], 992-999. https://doi.org/10.1016/j. cemconcomp.2007.12.003.

17. Valencia Saavedra, W.G.; Mejía de Gutiérrez, R. (2017) Performance of geopolymer concrete composed of fly ash after exposure to elevated temperatures, Constr. Build. Mater. 154, 229-235. https://doi.org/10.1016/j. conbuildmat.2017.07.208.

18. Rovnaník, P.; Bayer, P.; Rovnaníková, P. (2013) Characterization of alkali-activated slag paste after exposure to high temperatures, Constr. Build. Mater. 47, 14791487. https://doi.org/10.1016/j.conbuildmat.2013.06.070.

19. Śkvára, F.; Jílek, T.; Kopecký, L. (2005) Geopolymer materials based on fly ash, Ceram.-Silik. 49 [3], 195-204.

20. Bakharev, T. (2006) Thermal behaviour of geopolymers prepared using class $F$ fly ash and elevated temperature curing, Cem.Concr.Res. 36 [6], 1134-1147. https://doi. org/10.1016/j.cemconres.2006.03.022.

21. Garcia-Lodeiro, I.; Palomo, A.; Fernández-Jiménez, A.; Macphee, D.E. (2011) Compatibility studies between $\mathrm{N}-\mathrm{A}-\mathrm{S}-\mathrm{H}$ and C-A-S-H gels. Study in the ternary diagram $\mathrm{Na}_{2} \mathrm{O}-\mathrm{CaO}-\mathrm{Al}_{2} \mathrm{O}_{3}-\mathrm{SiO}_{2}-\mathrm{H}_{2} \mathrm{O}$, Cem. Concr.Res. 41 [9], 923-931. https://doi.org/10.1016/j.cemconres.2011.05.006. 
22. Alahrache, S.; Winnefeld, F.; Champenois, J.-B.; Hesselbarth, F.; Lothenbach, B. (2016) Chemical activation of hybrid binders based on siliceous fly ash and Portland cement, Cem. Concr. Compos. 66, 10-23. https:// doi.org/10.1016/j.cemconcomp.2015.11.003.

23. Qu, B.; Martin, A.; Pastor, J.; Palomo, A.; FernándezJiménez, A. (2016) Characterisation of pre-industrial hybrid cement and effect of pre-curing temperature, Cem. Concr. Compos. 73, 281-288. https://doi.org/10.1016/j. cemconcomp.2016.07.019.

24. Fernández-Jiménez, A.; Garcia-Lodeiro, I.; Maltseva, O.; Palomo, A. (2018) Hydration mechanisms of hybrid cements as a function of the way of addition of chemicals, J. Am. Ceram. Soc. 102, 427-436. https://doi.org/10.1111/ jace. 15939

25. Luukkonen, T.; Abdollahnejad, Z.; Yliniemi, J.; Kinnunen, P.; Illikainen, M. (2018) One-part alkali-activated materials: A review, Cem. Concr. Res. 103, 21-34. https://doi. org/10.1016/j.cemconres.2017.10.001.

26. L'Hôpital, E.; Lothenbach, B.; Scrivener, K.; Kulik, D.A. (2016) Alkali uptake in calcium alumina silicate hydrate (C-A-S-H), Cem.Concr.Res. 85, 122-136. https://doi. org/10.1016/j.cemconres.2016.03.009.

27. Garcia-Lodeiro, I.; Fernandez-Jimenez, A.; Palomo, A. (2013) Hydration kinetics in hybrid binders: Early reaction stages, Cem. Concr. Compos. 39, 82-92. https://doi. org/10.1016/j.cemconcomp.2013.03.025.

28. Kovalchuk, G.; Krienko, P.V. (2009)12 - Producing fireand heat-resistant geopolymers, in J.L. Provis, J.S.J. van Deventer (Eds.) Geopolymers, pp 227-266. Woodhead Publishing.

29. Aranda, M.A.G.; De La Torre, A.G.; León-Reina, L. (2012) Rietveld quantitative phase analysis of OPC clinkers, cements and hydration products, Rev. Mineral. Geochem. 74 [1], 169-209. https://doi.org/10.2138/rmg.2012.74.5

30. Timoshenko, S.P.; Young, D.H. (1956) Engineering mechanics, New York.

31. Kübler, J. (1999) Fracture toughness of ceramics using the SEVNB method; round robin. In ECF13, San Sebastian 2000.

32. Fernández-Jiménez, A.; Palomo, A.; Pastor, J.Y; Martín, A.; (2008) New cementitious materials based on alkaliactivated aly ash: performance at high temperatures, J. Am. Ceram. Soc. 91 [10], 3308-3314. https://doi. org/10.1111/j.1551-2916.2008.02625.x.

33. Fernández-Jiménez, A.; Pastor, J.Y.; Martín, A.; Palomo, A. (2010) High-temperature resistance in alkali-activated cement, J. Am. Ceram. Soc. 93[10], 3411-3417. https://doi. org/10.1111/j.1551-2916.2010.03887.x.

34. Martin, A.; Pastor, J.Y.; Palomo, A.; Fernández-Jiménez, A. (2015) Mechanical behaviour at high temperature of alkali-activated aluminosilicates (geopolymers), Constr. Build. Mater. 93, 1188-1196. https://doi.org/10.1016/j. conbuildmat.2015.04.044.

35. Stepkowska, E.; Perez-Rodriguez, J.; De Haro, M.J.; Sayagues, M. (2002) Study of hydration of two cements of different strengths, J. Therm. Anal. Calorim. 69, 187-204. https://doi.org/10.1023/A:1019902210255.

36. Donatello, S.; Kuenzel, C.; Palomo, A.; Fernández-Jiménez, A. (2014) High-temperature resistance of a very high volume fly ash cement paste, Cem. Concr. Compos. 45, 234-242. https://doi.org/10.1016/j.cemconcomp.2013.09.010.

37. Swartz, S.; Yap, S. (1986) Evaluation of recently proposed recommendations for the determination of fracture parameters for concrete in bending. In Experimental Stress Analysis, pp. 233-244. Springer

38. Nallathambi, P.; Karihaloo, B.; Heaton, B. (1984) Effect of specimen and crack sizes, water/cement ratio and coarse aggregate texture upon fracture toughness of concrete, Mag. Concr. Res. 36 [129], 227-236. https://doi.org/10.1680/ macr.1984.36.129.227.

39. Sih G.C. (1984)Fracture mechanics of engineering structural components. In: Sih G.C., de Oliveira Faria L. (eds) Fracture Mechanics Methodology. Engineering Applications of Fracture Mechanics, vol 1. Springer, Dordrecht.

40. Elices, M.; Planas, J. (1996) Fracture mechanics parameters of concrete: an overview, Adv. Cement. Base. Mater . 4 [3-4], 116-127. https://doi.org/10.1016/S1065-7355(96)90080-2.

41. Djaknoun, S.; Ouedraogo, E.; Benyahia, A.A. (2012) Characterisation of the behaviour of high-performance mortar subjected to high temperatures, Constr. Build. Mater. 28 [1], 176-186. https://doi.org/10.1016/j. conbuildmat.2011.07.063.

42. Sukontasukkul, P.; Pomchiengpin, W.; Songpiriyakij, S. (2010) Post-crack (or post-peak) flexural response and toughness of fibre reinforced concrete after exposure to high temperature, Constr. Build. Mater. 24 [10], 1967-1974. https://doi.org/10.1016/j.conbuildmat.2010.04.003.

43. Sarker, P.K.; Haque, R.; Ramgolam, K.V. (2013) Fracture behaviour of heat cured fly ash based geopolymer concrete, Mater. Des. 44, 580-586. https://doi.org/10.1016/j. matdes.2012.08.005.

44. Guinea, G. Pastor, J.Y.; Planas, J.; Elices, M. (1998) Stress intensity factor, compliance and CMOD for a general threepoint-bend beam, Int. J. Fract. 89 [2], 103-116. https://doi. org/10.1023/A:1007498132504.

45. Silva, D.A.; John, V.M. Ribeiro J.L.D; Roman, H.R. (2001) Pore size distribution of hydrated cement pastes modified with polymers, Cem. Concr.Res. 31 [8], 1177-1184. https://doi.org/10.1016/S0008-8846(01)00549-X.

46. Qu, B., (2018) Temperature effect on performance of Portland cement versus advanced hybrid cements and alkali-fly ash cement, $\mathrm{PhD}$ thesis, Department of Materials Science, E.T.S.I. Caminos, Canales y Puertos, Universidad Politécnica de Madrid, Madrid, Spain.

47. Qu, B., Martin, A.; Pastor, J.Y.; Palomo, A.; FernándezJiménez, A. (2019) Characterization of alkaline hybrid cement after exposure to high temperature, J. Am. Ceram. Soc. Submitted.

48. Puertas, F.; Palacios, M.; Manzano, H.; Dolado, J.S. ; Rico, A.; Rodríguez, J. (2011) A model for the C-AS-H gel formed in alkali-activated slag cements, J. Eur. Ceram. Soc. 31 [12], 2043-2056. https://doi.org/10.1016/j. jeurceramsoc.2011.04.036

49. Shi, C.; Day, R.L. (2000) Pozzolanic reaction in the presence of chemical activators: Part I. Reaction kinetics, Cem.Concr.Res. 30 [1], 51-58. https://doi.org/10.1016/ S0008-8846(99)00205-7.

50. Shi, C.; Day, R.L. (2000) Pozzolanic reaction in the presence of chemical activators: Part II - Reaction products and mechanism, Cem.Concr.Res., 30 [4], 607-613. https:// doi.org/10.1016/S0008-8846(00)00214-3.

51. Sánchez-Herrero, M.J.; Fernández-Jiménez, A.; Palomo, A. (2017) $\mathrm{C}_{3} \mathrm{~S}$ and $\mathrm{C}_{2} \mathrm{~S}$ hydration in the presence of $\mathrm{Na}_{2} \mathrm{CO}_{3}$ and $\mathrm{Na}_{2} \mathrm{SO}_{4}$, J. Am. Ceram. Soc. 100 [7], 3188-3198. https:// doi.org/10.1111/jace.14855.

52. Pan, Z: Sanjayan, J.G.; (2010) Stress-strain behaviour and abrupt loss of stiffness of geopolymer at elevated temperatures, Cem. Concr. Compos. 32 [9], 657-664. https://doi. org/10.1016/j.cemconcomp.2010.07.010.

53. Pan, Z.; Sanjayan, J.G.; (2012) Factors influencing softening temperature and hot-strength of geopolymers, Cem. Concr. Compos. 34 [2], 261-264. https://doi.org/10.1016/j. cemconcomp.2011.09.019. 